\title{
Hospitalization-Associated Disability in Adults Admitted to a Safety-Net Hospital
}

\author{
Edgar Pierluissi, $M D^{1,2}$ \\ 'Division of Hospital Medicine and Geriatrics, University of California, San Francisco, San Francisco, CA, USA; ${ }^{2}$ San Francisco General Hospital, San \\ Francisco, CA, USA.
}

$J$ Gen Intern Med 31(5):461

DOI: $10.1007 / \mathrm{s} 11606-016-3619-0$

(c) Society of General Internal Medicine 2016

$\mathrm{W}$ e appreciate Dr. Schattner's valuable letter regarding our paper. We agree that mood and cognition are important factors and outcomes to assess in studies of hospitalized older adults. Studies ${ }^{1,2}$ have clearly shown the importance of these factors in contributing to functional decline in the hospital and afterwards. Evidence is strong, however, that these are rarely measured in clinical practice. $^{3}$

We disagree however, that "a material flaw" exists in the definition of hospitalization-associated disability (HAD). The definition we used in our study, "1) new ADL disability (needing help performing any of the five ADLs for which the participant did not need help at baseline 2 weeks before admission) or 2) death," has been used in many studies and is considered a standard. ${ }^{4}$ Disability after hospitalization is an important predictor of institutionalization and further decline and mortality. ${ }^{5}$ In addition to measuring new-onset disability, studies of hospitalized-older adults should also measure mood and cognition, important risk factors and outcomes in their own right.

Corresponding Author: Edgar Pierluissi, MD; San Francisco General Hospital, 1001 Potrero Avenue, Room 5H17, San Francisco, CA 94110, USA (e-mail: Edgar.Pierluissi@ucsf.edu).

\section{Compliance with Ethical Standards:}

Conflict of Interest: The author declares that he does not have a conflict of interest.

\section{REFERENCES}

1. Mehta KM, Pierluissi E, Boscardin WJ, Kirby KA, Walter LC, Chren MM, Palmer RM, Counsell SR, Landefeld CS. A clinical index to stratify hospitalized older adults according to risk for new-onset disability. J Am Geriatr Soc. 2011;59(7):1206-16.

2. Pierluissi E, Mehta KM, Kirby KA, et al. Depressive symptoms after hospitalization in older adults: function and mortality outcomes. J Am Geriatr Soc. 2012;60(12):2254-62.

3. Boustani M, Baker M, Campbell N, Munger S, Hui S, Castelluccio P, et al. Impact and recognition of cognitive impairment among hospitalized elders. J Hosp Med. 2010;5(2):69-75.

4. Covinsky KE, Pierluissi E, Johnston CB. Hospitalization-associated disability: "she was probably able to ambulate, but I'm not sure". JAMA. 2011;306(16):1782-93.

5. Boyd CM, Landefeld CS, Counsell SR, Palmer RM, Fortinsky RH, Kresevic D, et al. Recovery of activities of daily living in older adults after hospitalization for acute medical illness. J Am Geriatr Soc. 2008;56(12):2171-9. 